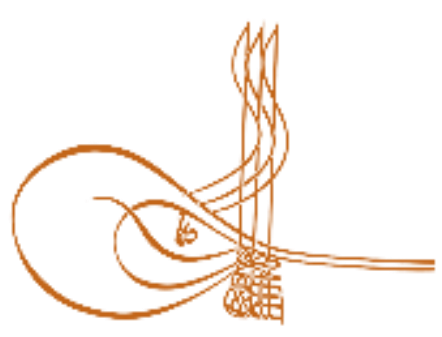

www.turkishstudies.net/social
Turkish Studies - Social Sciences

eISSN: $2667-5617$

Research Article / Araștırma Makalesi

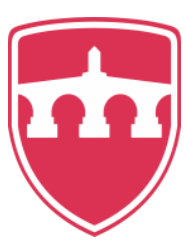

INTERNATIONAL

BALKAN

UNIVERSITY

Sponsored by IBU

\title{
Çoksesli Müzik Terminolojimiz ve Terimlerimiz Üzerine Bazı Düşünceler
}

Some Thoughts on Our Polyphonic Musical Terminology and Terms

\author{
Bertan Rona*
}

\begin{abstract}
Ottoman musicians who met with polyphonic music in Tanzimat era were not very successful in understanding the distinguishing qualities of polyphonic music, its terminology reflecting these qualities and transferring it to the Turkish language. However, this situation had been impasse by proceeding negatively in conjunction with inconsistencies encountered in the origins of the Western languages as well as Turkish language purification studies. After this date, the attempts to derivation of terms remain limited to individual approaches and these approaches have been inadequate for creating a common language. In this study, first the terms atonal, çeken, uyum, eksik and müzikbilim were subjected to critical reading and inconsistencies in Western and Turkish languages were pointed out. Then, some special situations of Turkish languages were underlined by examining çalgl, çoksesli, aria and arya terms. After that, the terms karar and perde which are belong to Turkish music, deprived of interaction of polyphonic musical terminology, were emphasized and it was asked about what could be expressed by interdisciplinary communication. And finally, by putting emphasis on rehearsal terms çekmek, koşmak, yaslanmak, oturmak and singing terminology such as beyaz and kemikli ses, it has been noted that those terminologies are needed to be added to dictionaries. Today's world is a world of the free market, communication world that has left behind even post-modernity. The period we are in; it is an era in which all cultures and languages are interacting very quickly and a market formed by eclectic products consumed very quickly dominate everyone. Under these conditions, producing an effective Turkish polyphonic music terminology may seem difficult, however scene of Germany which is further than Turkey in terms of polyphonic music shows that it's not impossible. The way to this goal is through works of our musicologist and cooperation that they can be involved.
\end{abstract}

Structured Abstract: The clash between "traditionalism" and "modernism" in Turkey and similar countries is a phenomenon well known. Although the deep disagreements caused by the clash in question have a political and ideological basis, its repercussions can be observed in almost all superstructure institutions and in the language as well. After Tanzimat (the Reforms), within the scope of the Westernization movement, which gained momentum especially with the proclamation of the Republic, significant interventions were made to the Turkish of the day. As a result of these interventions, though successful purification works were achieved, the expression tools of the Turkish language, which used to be an imperial language, were partially

\footnotetext{
${ }^{*}$ Dr. Öğr. Üyesi, Giresun Üniversitesi Devlet Konservatuvarı, Müzik Bölümü Asst. Prof. Dr., Giresun University, Conservatoire, Department of Music ORCID 0000-0001-5009-2183

bertanrona@gmail.com

Cite as/ Atıf: Rona, B. (2020). Çoksesli Müzik terminolojimiz ve terimlerimiz üzerine bazı düşünceler, Turkish Studies - Social, 15(1), 577-589. https://dx.doi.org/10.29228/TurkishStudies.40134

Received/Geliş: 12 December/Aralık 2020

Accepted/Kabul: 25 February/Şubat 2020

Checked by plagiarism software

Copyright $($ INTAC LTD, Turkey

Published/Yayın: 29 February/Şubat 2020

CC BY-NC 4.0
} 
weakened. When the transition to the Latin alphabet was added to this sharp transformation, a situation in which it was difficult to produce science, philosophy and art was encountered. When the terminology of music in Turkish is concerned, it is seen that other factors were also involved in the general picture we tried to describe above. Getting acquainted with polyphonic music, learning about this music and producing works within the framework of this type of music in our country were only made possible with the introduction of Tanzimat. In that period, polyphonic music was in quite a contrast to the cultural accumulation of the Ottoman civilization as it had almost no equivalent in the lands of our country and was not known as a concept. Therefore, the alienation and ignorance about this music has left the music terminology, which is tried to be developed by groping with individual efforts, without a foundation. The work of musicologists and composers such as Mahmut Ragıp Gazimihal, Ahmed Adnan Saygun, Ertuğrul Oğuz Firat, Gültekin Oransay and Muammer Sun in the Republican period did not produce the desired result, either. The fact that the founding ideology of the state, which gave a special emphasis on polyphonic music, gradually lost its influence in the political field especially after the one-party rule period and the resulting loss of coordination in polyphonic music works and lack of central government's interest in it had a great influence on the development of this situation. In this study, a critical reading of some established terms as examples of today's Turkish music terminology (atonal, pulling, harmony, missing, musicology) was included, and then some suggestions were made by emphasizing some special situations and opportunities. Western languages, which are usually of Latin origin, have produced serious terminological inaccuracies in the historical process. An example to these is the term atonal. The term refers to "non-tonality", but it also means "without pitch" as a word. However, a music piece without a pitch cannot be mentioned. This example illustrates the problem of an imported term commonly used in Turkish polyphonic music terminology. Another example of translation problems in Turkish polyphonic music terms in our language is the term pulling used for the term dominant. But using a term derived from the verb "to pull" to mean dominantis quite problematic. Because in tonal music, each sound can pull another sound within the framework of functional relations. Even, because it determines tonality, axis can be said to be the pitch that pulls the most. As another problematic translation example, the term harmony can be given. The real problem here is that the term harmony and the term consonant are both translated into Turkish to mean harmonious. Because in our polyphonic music terminology, consonant and disonante are translated as harmonious and disharmonious, but the expressions harmonie consonant andharmonie disonante noun phrases will be translated into Turkish as meaningless phrases of harmonious harmony and disharmonious harmony. Among our most established terms, the term missing also shares a similar fate as the termharmony. The fact that this term is used as an adjective that modifies both tones and chords with one sound removed prevents these concepts from having a clear meaning. The term musicology does not comply with the rules of Turkish, either. When the structural features of our language are taken into account, insisting on the use of the term that should be composed of two words as music science in Turkish as a one word in the form of musicology brings about the problem of what term should be used for the term musicologist. There are some special situations and possibilities that Turkish offers in terms of music terms. The term instrument which expresses the concept in one word instead of two words as musical instrument is among them. The intonation difference between the terms Polyphonic and the term çok sesli (poly phonic) is also a delicacy that needs to be emphasized. Depending on the preferences of Turkish over time, different applications on how to spell words borrowed from foreign languages as in the example of aria and arya which provides various labeling possibilities are another richness that should be mentioned. Based on the ideas put forward in this article, it can be said that two of the suggestions that can be made for our polyphonic music terminology are related to benefiting from contact with the classical Turkish music and rehearsal terminology. It should be noted that terminology derivation requires collective as well as individual effort. However, it is very difficult to create a common terminology language today. Today's Turkey, which is characterized by free market economy and the path towards urbanization, is not immune from developments experienced in communication and transportation all over the world. The world we live in is a place in which all cultures, languages and arts are interacting very quickly, forms which are devoid of contents can be imitated easily, educated individuals increasingly become more complicated, and markets formed by eclectic products that are quickly consumed dominate everyone. In such a world, it is very difficult to draw a national culture picture inspired and provided by modernism. Polyphonic music terminology, which will constitute one of the figures of this picture, is encountering and will continue to encounter the same obstacles. On the other hand, national cultures created and conserved by urbanized and capitalist industrial countries such as France and especially Germany are also a case. For example, Germany, as one of the world's greatest powers in the political and economic field, has been able to ensure a national character for its entire culture, although it is a country that fully lives post-modernity with

Turkish Studies - Social, 15(1) 
its important opportunities in technology, communication and transportation. Although German musicians interact much more internationally than their Turkish counterparts, the music terminology they use has a much more national character than Turkish polyphonic music terminology. Thus, creating a Turkish polyphonic music terminology in Turkey is not an impossible task. However, it does not seem possible to achieve this through a central coordination. All that remains is the individual efforts of our talented and hardworking musicologists in this field. Whether the fruits of these studies can be really collected or not and whether a common language on polyphonic music terminology can be developed ot not are the subjects of a separate study.

Keywords: Musicology, Turkish polyphonic music terms, Terminology.

Öz: Çoksesli müzikle Tanzimat döneminde tanışan Osmanlı müzisyenleri, öğrenilecek olan bu yeni müzik türüne oldukça uzak bir kültüre mensup olduklarından, çoksesli müziğin ayırt edici niteliklerini ve bu nitelikler üzerinde yükselen terminolojisini anlayıp Türkçeye aktarmakta çok başarılı olamamışlardır. Ne var ki aslen son derece doğal olan bu durum, söz konusu terimlerin Batı dillerindeki orijinallerinde karşılaşılan tutarsızlıkların yanı sıra, Türkçede özleşme çalışmalarının da etkisiyle aradan geçen yıllara rağmen olumsuz yönde gelişerek içinden çıkılmaz bir hâl almıştır. Bu tarihten sonra ise terim çevirme ve türetme çabaları, bireysel yaklaşımlarla sınırlı kalmış, merkezî bir yönlendirmeden mahrum kalan bu yaklaşımlar ise meslek terimciliğimizde ortak bir dil oluşturulmasına yetmemiştir. Bu çalışmada önce, atonal, çeken, uyum, eksik ve müzikbilim terimleri eleştirel bir okumaya tabi tutulmuş ve hem Batı dillerinde hem de Türkçede müzik terimlerinin tutarsızlıklarına işaret edilmiştir. Ardından çalgı, çoksesli, aria ve arya terimleri incelenerek, Türkçenin yapısından kaynaklanan bazı özel durumların altı çizilmiştir. Bundan sonraysa çoksesli müzik terimciliğimizin etkileşimden yoksun kaldığı klasik Türk musıkisinin ıstılahlarından karar ile perde üzerinde durularak, disiplinlerarası bir temasın neyi ifade edebileceği sorusu sorulmuştur. Ve nihayet, çekmek, koşmak, yaslanmak, oturmak gibi prova terimleriyle, beyaz ses ve kemikli ses gibi şan terimleri üzerinde durularak bu tür terimlerin sözlüklerde yer alması gerektiği belirtilmiştir. Günümüz dünyası, postmoderniteyi bile geride bırakmış bir serbest pazar, iletişim ve ulaşım dünyasıdır. İçinde bulunduğumuz çağ; bütün kültürlerin, dillerin ve sanat dallarının çok hızlı bir etkileşim içinde olduğu ve çok çabuk tüketilen eklektik ürünlerden oluşan bir piyasanın herkesi domine ettiği bir çağdır. Bu koşullar altında millî karakterde ve etkili bir Türkçe çoksesli müzik terminolojisi ortaya koymak zor görünse de örneğin çoksesli müzikte Türkiye'den daha ileride olan Almanya'nın bu konuda sergilediği tablo, bunun imkansız olmadığını ortaya koymaktadır. Bu hedefe giden yol, günümüzde yetenekli ve çalışkan müzikologlarımızın gerçekleştirecekleri çalışmalardan ve işbirliğinden geçmektedir.

Anahtar Kelimeler: Müzikoloji, Türkçe çoksesli müzik terimleri, Terminoloji.

\section{Giriş}

Modernite ile yüzlerce yıl geç, üstelik kendi iç dinamikleri dışında tanışan Türkiye ve benzeri ülkelerde "gelenekçilik" ile "modernizm" arasındaki (aslen siyasal temelli) büyük kırılma, iyi bilinen bir olgudur. Türkiye'de söz konusu kırılmanın yarattığı derin görüş ayrılıkları siyasiideolojik temelli olsa da yansımasını üstyapı kurumlarının hemen hepsinde, bu arada dilde de bulmuştur. Tanzimat sonrasında, özellikle Cumhuriyet'in ilanıyla birlikte büyük hız kazanan Batılılaşma hareketi kapsamında, o günkü Türkçeye ciddi müdahaleler söz konusudur. Türkçede yapılmak istenen değişiklikler sadece Arapça ve Farsça kökenli kelimelerin dilden atılması değil, eski Asya Türkçesinin bazı özelliklerinin yeniden canlandırılması ve Avrupa dillerinin birtakım modellerine öykünülmesi biçimindedir. Ancak neredeyse bin yıldır Türkçede yaşayan ve sayısız deyimde kendine özgü bir anlatım ve duyuluş değeri kazanmış olan yabancı kökenli kelimelerin dilden atılmasında zaman zaman aşırıya gidilmiştir. Bunun sonucunda, (gerçekten gerekli ve başarılı özleştirme çalışmaları bir yana bırakacak olursak) yaklaşı beş yüzyıllık bir imparatorluk dili olan Türkçe'nin ifade araçları zayıflamıştır. Bu keskin değişimlere, Latin alfabesine geçiş de eklenince, bilim, felsefe ve sanat üretmeyi zorlaştıran bir manzara ile karşılaşılmıştır. Yeni nesiller, ancak kavramlarla yapılabilen bilim ve felsefeyi üretmekte zorlanmış, eski yazı bilmedikleri için geçmiş yapıtları inceleyerek gelenekle bağ kuramadıklarından müzikoloji de dahil olmak üzere pek 
çok alanda atıl kalmışlardır. Günümüz gençleri ise eski kitapları okumak şöyle dursun, en genel anlamda gündelik düşünceyi işletecek donanımdan da yoksun, söz gelimi "mecbur" ile "cebir" veya "mezun" ile "izin" arasındaki bağdan, "istidat" ile "kabiliyet" arasındaki nüanstan, "zaten"in "zat"tan geldiğinden bile tamamen habersizdirler. Post-modernite yıllarının, iletişim çağının, hatta günümüz "bilgi" toplumunun bunun dışında bir duruma izin verip vermeyeceği, ayrı bir tartışmanın konusudur.

Öte yandan, Türkçe ile ilgili olarak yaşanan olumsuz gelişmelerin, tuhaf bir biçimde bu dilin lehine değerlendirilebilecek yönleri olduğunu da belirtmek gerekir. Dile gereksiz sokulmuş, hatta yanlış türetilmiş olan sayısız kelime Türkçede tutunmuş, bununla birlikte "eski"leri de kullanılmaya devam etmiş, böylelikle pek çok nesne ve kavramın, biri eski, biri yeni olan karşılıkları olmuştur. Bazen de halk bunun gibi kelimeler üzerinde türlü tasarruflarda bulunmuş, dolaşıma sokulmak istenen yeni kelimeyi kendi anlayışına göre kullanmaya başlamıştır. Mesela ivedi kelimesini benimsememiş, ancak ondan türetilmiş olan ivedilikle zarfını kullanmıştır. Ya da 1944 Derleme Dergisi’nde göründükten sonra 1945 TDK Sözlüğü'nde yer alan ve hareket kelimesi karşılığında önerilmiş olan devinim kelimesini kabul etmiş ancak onu hareket kelimesinin yerine geçirmeyerek, dilde tuttuğu hareketin yan anlamlısı olarak dönüşüme uğratmıştır. Buna göre hareket, "bir noktadan bir başka noktaya doğru ilerleme" anlamındayken, devinim ise daha çok "kendi olduğu yerde kımıldama, kaynama, dalgalanma, debelenme" ve benzeri içsel hareketleri ifade etmektedir. (İngilizcedeki movement ile motion ayrımı gibi.) (Nişanyan, 2019: 359-360)

Türkçe müzik terimlerine geldiğimizde, yukarıda betimlemeye çalıştığımız tabloya daha başka figürlerin de katıldığı görülmektedir. Bilindiği üzere çoksesli müzikle tanışma, bu müziği öğrenme ve bu müzik çerçevesinde yapıt verme, ülkemizde ancak Tanzimat'la birlikte söz konusu olmuştur. O tarih itibarıyla bakıldığında çoksesli müzik, Osmanlı medeniyetinin kültür birikimine oldukça zıt nitelikte, ülkemiz topraklarında neredeyse hiç karşılığ hemen hemen hiç tanınmayan bir müzik türüdür. Dolayısıyla bu müzik karşısındaki yabancılık ve bilgisizlik, el yordamı ve bireysel çabalarla geliştirilmeye çalışılan müzik terminolojisini temelsiz bırakmıştır. O dönemde pek çok terim hatalı çevrilmiş veya türetilmiştir. Kâzım Uz'un 1894'te yayımladığı Musiki Istılâhatı adlı kitapçıkta majör teriminin diyez anlamına geldiğinin belirtilmesi, bu konuda yaşanan kafa karışıklığına ilişkin çarpıcı bir örnektir. (Uz, 1964: 42) Buna, Batı dillerindeki terminolojide görülen tutarsızlıklar, hatta yanlışlar eklendiğinde, iş iyice karmaşık bir hâl almıştır. Oysa ki terminoloji, bir bilim veya sanat dalının, ya da felsefenin sağlam temeller üzerinde yükselip gelişmesi açısından hayati bir önemi haizdir. Bilimin uluslararası yanı, yöntemleridir. (Sinanoğlu, 1978: 1) Dili değildir. Yukarıda zımnen ifade ettiğimiz, "dilin bin yıllık kelimelerinin, kökenleri ne olursa olsun korunması gerektiği, aslolanın halkın gündelik dili olduğu" görüşü, aslında terminoloji açısından geçersizdir. Dahası terminolojinin, bunun tam tersini gerektirdiği söylenebilir. Zira terminoloji, belirli bir alanın uzmanları arasında anlam bulanıklığını önleyen (İmer, Kocaman, Özsoy, 2011: 240) ve dolayısıyla aslen o işin uzmanları tarafindan anlaşılması gereken bir üst dildir. Bu bakımdan, köken kaygısından bağımsız olmak kaydıyla, halkın anlaması gibi bir kriterden yola çıkmak zorunda değildir. Nitekim "terimler, halkın söz varlığında yer almaz." (Zülfikar, 2011: 21)

Türkiye'deki çoksesli müzik terimciliğinin tarihçesinin vermek, bu makalenin kapsamı dışında olmakla beraber, tam bu noktada kısaca şu hususların belirtilmesinde yarar bulunmaktadır: Mahmut Ragıp Gazimihal, 1961 tarihli Musıki Sözlüğ̈̈’nde, Türkçe çoksesli müzik terimleri konusunda bahsedilebilecek ilk çalışmanın, Hüseyin Remzi'nin 1875 yılında Alex. Garaudé'den yaptığ 1 bir çeviri olduğunu ifade etmekte, ayrıca Mehmet Zati'nin, Saffet Atabinen'in Marmontel'den yaptığı teori kitabı tercümesini temel alarak yazdığ 1900 tarihli Nazariyat-ı Musıki'nin de bu alanda sözü edilmesi gereken başka bir kaynak olduğunu aktararak, "arada çeyrek asır geçtiği hâlde tabirler arasında kargaşalık beliriverdiğini görmek hazin bir manzara tesiri bırakıyor" demektedir. (Gazimihal, 1961: Önsöz) Gazimihal ayrıca, Türk Dil Kurumu'nun Terim Anketleri: Müzik başlı̆̆ı altında, 1954'te 27 sayfalık özel bir broşür çıkarıp ilgililere dağıttığını ve 
(1961 yılı itibarıyla) son yıllarda çıkarılan kişisel terim listelerinin istikrarı dağıtmasından kaygı duyduğunu, olup bitenlerin terimciliğimizin tarihinde hatıra kalmasını umduğunu ve zamanın terimciliği daha da millîleştireceğini öngördügünü de belirtmektedir. Ne var ki İlhan Usmanbaş'ın, André Hodeir'den çevirdiği Müzikte Türler ve Biçimler' in 2003 tarihli baskısının "Çevirenin Notu" kısmının daha ilk cümlesinde kendini "Bir müzik yazısının Türkçe çevirisi ergeç bir terim bilgisi açıklamasıyla son bulmak zorundadır bugün" demek zorunda hissetmesi, yirmi beş değil tam kırk y1llık bir aradan sonra oluşan yeni bir "hazin manzara"ya işaret etmektedir. (Hodeir, 2003: 7)

Aslında Gazimihal'in Musıki Sözlüğ̈̈'nün kendisi de terim türetme açısından önemli, hatta çok önemli bir başvuru kaynağıdır. Zira Gazimihal, "İçindekilere Dair" başlıklı kısımda, sözlüğündeki "tam çevirme" terim sayısının, binin üzerinde olduğunu ve bunlardan yüz kadarının da Ahmed Adnan Saygun tarafindan türetildiğini belirtmektedir. Tüm bu terimler, sözlüğün arkasında Fransızcadan Türkçeye ve Türkçeden Fransızcaya iki ayrı indeks hâlinde yer almaktadırlar. Yapıtın basıldığı 1961 yılından itibaren söz konusu terimler pek çok değerli müzik insanı tarafindan müzik okullarında kullanılmış olsalar da Gazimihal'in yurt genelinde hayal ettiği birlik gerçekleşememiştir. Üstelik Gazmihal'in sözünü ettiği kişisel çalışmaların, onun ölümünden sonra artarak devam ettiği anlaşılmaktadır. Bu alandaki pek çok isim arasında Ertuğrul Oğuz Fırat, Gültekin Oransay ve Muammer Sun'u anmak mümkündür. Ne var ki bu besteci ve müzikbilimciler de özveriyle gerçekleştirdikleri çok önemli çalışmalara karşın, istenen hedefe ulaşamamışlardır. Bunda, devletin çoksesli müziğe yakın olan kurucu ideolojisinin, özellikle tek partili dönem sonrasında siyasal alandaki etkisini tedricen yitirmesi ve buna bağlı olarak koordinasyonunu kaybeden çoksesli müzik çalışmalarının, merkezî bir ilgiden mahrum kalmasının etkisi büyüktür. İşte kurumsallaşmanın kaybedildiği bu ortamda, pek çok alanda olduğu gibi terminoloji alanında da kişiler kurumlaşmak durumunda kalmışlardır. Gerçekten de bugün Gazimihal, Saygun, Fırat, Oransay ve Sun gibi meslek erbabının tamamı, adeta tek başlarına birer kurumdurlar. Bu durumun doğurduğu başlıca sonuç ise aynı kavramın bazen üç hatta dört karşılığının olmasıdır. Kontrapunt, kontrpuan, karşıezgi ve girdi buna örnek gösterilebilir. Ancak yukarıda Türkçe lehine kullanılabileceğini söylediğimiz bazı imkanlar, özelde Türkçe müzik terminolojisi için de gerçerlidir. Nitekim Usmanbaş da az önce adı geçen çalışmasında şunları ifade etmektedir: “... yapılan çeviri, Batı terim bilgisinin birçok yanlışları, gereksizlikleri, sapmaları, bugünkü Türkçemizin eksiklikleri, yanlışlıkları, kararsızlıklarıyla birleşiyor, işi çok zorlaştırıyor. Ama belki iki kat da eğlenceli ve yararlı kılıyor. Alışkanlıkların, gözü kapalılığın dışına çıkıyor insan, dilleri yeniden düşünüyor, başkalarıyla karşılaştırıyor..." (Hodeir, 2003: 7)

Aşağıda, "Giriş" bölümü boyunca, sözü edilen tüm bu gerekleri karşılamak ve eldeki malzemeyi değerlendirmek amacıyla önce, örnek niteliğindeki bazı yerleşik terimlerin eleştirel okumasına yer verilmiş, ardından da kimi özel durumlar ve imkanlar üzerinde durularak birtakım önerilerde bulunulmuştur.

\section{Bazı Yerleşik Terimlerin Eleştirel Okuması}

Atonal: Genellikle Latince kökenli olan Batı dilleri, çoksesli müzik terminolojisinin taşıyıcısı oldukları hâlde, tarihsel süreçte ciddi terim yanlışlıkları üretmişlerdir. Ancak artık yerleşmiş bulunan bu hatalı terimler, müzisyenlerin alışkanlıkları dolayısıyla terk edilememişlerdir. Bunlara örnek olmak üzere, atonal terimi gösterilebilir. Etimolojik açıdan bakıldığında, terim, Yunancada olumsuzluk bildiren $a$ öneki ile perde anlamdaki ton kelimesinin birleşmesinden (tam olarak bunun sıfat hâlinden) oluşmuştur. Yani "perdesi olmayan" gibi bir anlamı vardır. Oysa ki böyle bir müziğin imkansızlı̆ğ bir yana, terim güncel anlamıyla, "tonalitesi olmayan" müziği ifade etmektedir. Bilindiği üzere tonalite dışı müzik yazısı oldukça çeşitlidir, ancak dodekafoni yani oniki perde tekniği bile, "perdesi olmayan" anlamına gelmez. Hatta belki bütün perdelere en çok duyarlı olan müziğin bu tür müzik olduğu söylenebilir. Nitekim atonal terimini yanlış bulan ve oniki perde tekniğinin mucidi olan Schönberg'in, kendi müziği için pantonal terimini önermesi, bu gerçeğe işaret etmektedir. Stravinski de "atonal terimini kullananların onunla ne kastettiklerini bilmek 
istediğini" söylemiş ve atonal yerine antitonal terimini öne sürmüştür. (Stravinski, 2000: 35) Aslında bu meselenin temelinde, tonalite teriminin tondan türetilmiş olması bulunmaktadır. Çünkü tonalite, "tonluluk" demektir, oysa ton yani perde içermeyen bir müzik söz konusu olamaz. Bu nedenle tonalite dışı müzik ile perdesi olmayan müziği ayırt etmek imkansız hâle gelmiştir. Dolayısıyla sorun, tarihsel süreçte birtakım hataların birbirine eklenmesiyle oluşmuştur ve atonal terkibi, yukarıda da belirtildiği üzere artık bir sorun değil yerleşik terim olarak varlığını sürdürmektedir.

Çeken: Batı dilleri kaynaklı bir örneğin ardından Türkçe çoksesli müzik terimlerindeki çeviri problemlerine ilişkin bir örnek, dilimizde dominant karşıllğında konservatuvarlarda yaygın olarak öğretilen ve pratikte sıkça kullanılan çeken terimidir. Etimoloji sözlükleri, Latince kökenli olan dominant sıfatının, Latince dominantem fiilinden 13. yüzyılda Fransızcaya, oradan da 1450'lerde İngilizceye geçtiğini söylemektedir. Sıfatın anlam içerikleri arasında "hâkim olan, sahip olan, kural koyan" bulunmakla birlikte, ana vurgu noktası "efendi", "sahip" ve "güçlü" kavramlarında belirginlik kazanmaktadır. Sözlükler, tonalitenin eksenden sonraki en önemli perdesi olan ve onunla ayrılmaz bir ikili oluşturan beşinci dereceye dominant adının verilmesini ise 1819'a tarihlemektedirler. Ne var ki, beşinci derecenin tonalitenin sahibi veya efendisi konumunda bulunduğu ya da güçlü olduğunun son derece keyfî bir değerlendirmeyi ifade ettiğini belirtmek gerekir. Zira eğer bir "efendi" ya da "sahip"ten söz edilecekse, bunun, tonaliteyi belirleyen konumuyla bütün perdelere hükmeden eksen olduğunu söyleyebiliriz. "Güçlü" olmaya gelince... Akorların kendisine çözüldüğü ve parçanın sonunda varılan yer olan eksenin, yine tonalite içindeki en güçlü perde olduğu açıktır.

Türkçe çoksesli müzik terminolojisinde dominant teriminin çevirileri arasında güçlüden de yaygın olarak (ve altçeken ile bir ikili oluşturacak şekilde) en çok kullanılanı, çekendir. Bu terimin "hükmetmek, sahip veya güçlü olmak" değil, "çekmek" fillinden türetildiği görülmektedir. Gazimihal'in listesinde sansibl için duygun teriminin yanı sıra çekimlinin de kullanılmış olması, bu tercihin kapsamını anlamak bakımından önemlidir (sansibl, dominant ailesine mensup bir perdedir). Sansibl anlamında kullanılan yeden teriminin kökündeki "yedmek" fiilinin de "çekip götürmek" anlamına geldiği düşünülürse, bu konuda belirgin bir çerçevenin oluştuğu göz ardı edilemez. Ne var ki dominantın "çekmek" fiilinden türetilmiş bir terimle karşılanması, anlam bakımından oldukça sıkıntılıdır. Zira tonal müzikte, fonksiyonel ilişkiler çerçevesinde her ses bir başka sesi çekebilir. Bu açıdan yani yürüyücülük-duruculuk bağlamında bakıldığı zaman do, re'yi; $m i, f a$ 'yı; sol, la'y1 ve oktavdaki do da si'yi kendisine çekmektedir. Hatta tonaliteyi belirlediği için eksenin en fazla çeken perde olduğu da söylenebilir. Öyleyse çeken adının sadece beşinci dereceye tahsis edilmesi, açıklanmaya muhtaçtır. Dahası, dominant perdesine mutlaka "çekmek" fiilinden türetilmiş bir ad konulacaksa, bunun çekilen olması akla daha yatkındır. Çünkü sansiblden sonra (ve ikinci derece ile birlikte) eksene doğru en çok çekilen perde, dominant perdesidir.

Uyum: Bir başka sorunlu çeviri örneği olarak, uyum gösterilebilir. Bilindiği üzere bu terim, dilimize Fransızcadan giren armoni terimine karşılık olarak düşünülmüştür. Osmanlı Türkçesinde uzun yıllar yaşayan ancak maalesef günümüzde gittikçe daha az kullanılan ahenk gibi armoni de aslen "uyum" demektir. Latince fiilin anlam içeriklerinden birinin "eklenmek" olması, bu noktay1 daha anlaşılır kılmaktadır. Çünkü armoni bilimi de birbirine "uyduğu" için "eklenen" tonları inceleyen bir bilimdir. Dolayısıyla armoni teriminin "uyum" ile karşılanmasında bir sorun yok gibi görünmektedir. Halbuki gerçekte durum oldukça farklıdır. Çünkü kelimeler ve dolayısıyla terimler, tek başlarına var olan, müstakil birer dilbilim unsuru değildirler. Dil içinde yapısal olarak edindikleri karakter, ancak diğer unsurlarla girdikleri ilişki üzerinden tanımlanıp değerlendirilebilir. $\mathrm{Bu}$ bakımdan Türkçe müzik terimlerinin de öncelikle oluşturdukları tamlamalar açısından düşünülmesi gerekmektedir. Bir armoni kitabının kapağında armoni yerine uyum (veya uyum bilgisi) terimi kullanılabilir ancak bu tercihte bulunanları kitabın içinde birtakım sürprizler bekleyecektir. Çünkü özellikle Fransız tandanslı her armoni kitabı, harmonie consonant ile harmonie disonante olmak üzere iki bölümden oluşur ve dilimizde consonant ile disonante 
terimleri de uyumlu ve uyumsuz olarak karşılandığından, bu terkiplerin çevirisi uyumlu uyum ve uyumsuz uyum gibi son derece anlamsız birer tamlama biçiminde olacaktır. Uyuşumsuz uygu gibi benzer kullanımlara da rastlanmaktadır. (Korsakov, 1996: 4) Görüldüğü gibi buradaki asıl sorun, armoni teriminden çok consonant teriminin uyumlu biçiminde dilimize çevrilmesinden kaynaklanmıştır. Halbuki kelimenin etimolojisi bundan uzaktır. Ayrıca bu tablo çerçevesinde disonansın zorunlu olarak uyumsuz biçiminde çevrilmesi, başka bir yetersizlik kaynağıdır. Zira disonans ile birlikte tanımlanması gereken discordant teriminin bu durumda nasıl adlandırılacağı belirsizdir.

Eksik: Çoksesli müzik terminolojimizin en yerleşik terimleri arasında bulunan eksik de uyum ile benzer bir kaderi paylaşmaktadır. Zira armoni ile consonant terimlerinin her ikisinin de "uymak" fiili ile karşılanması nasıl karışıklıklara yol açıyorsa, eksik teriminin de hem aralıkları hem de bir sesi atılmış akorları niteleyen bir sıfat olarak kullanılması, söz konusu kavramların netleşmesine engel olmaktadır. Söz gelimi triton niteliğinde olan bir beşli aralık için eksik beşli denilmekte, benzer biçimde üçlüsü küçük ve beşlisi eksik olan bir akor için de eksik akor nitelemesi yapılmaktadır. Ancak bunlarla hiç ilgisi olmayan bir durumda, örneğin beşlisi atılmış bir dominant yedili olan sol-si-fa-sol akoru için de eksik terimi kullanılmaktadır. Doğal olarak kafa karıştıran bu durum, Batı dillerindeki diminish sıfatının başlangıçta Türkçeye eksik biçiminde çevrilmesinden ve bir sesi eksik olan akorları anlatmak üzere bir zamanlar okullarımızda öğretilen natamam teriminin Türkçenin güncel tercihlerinin de etkisiyle terk edilmesinden kaynaklanmıştır. Burada örnek bir çözüm; "tam olmayan" anlamındaki natamam teriminin günümüz Türkçesindeki karşılığ1 aslen eksik sıfatı olduğu için, bir sesi bulunmayan akorlara eksik akorlar denmesi, aralık veya akorlar için diminish karşılığında kullanılan terimin ise, (orijinalindeki gibi) "küçük-büyük" sıfatlarından türetilmesi ya da dar-geniş ikilisinden yola çıkılarak adlandırılması olabilir.

Müzikbilim: Hint-Avrupa dil ailesine bağlı olan Batı dilleri ile Ural-Altay dil ailesine bağlı olan Türkçe arasındaki önemli yapısal farklılıklar, herkesin malumudur. Bunlardan biri de, Türkçede Batı dillerinden farklı olarak, isim tamlamalarında tamlanan unsurun genellikle ek almasıdır. Buna örnek olarak "kış güneşi” ifadesindeki "güneş" kelimesinin sonuna gelen iyelik ekini (-i) gösterebiliriz. Oysa aynı tamlamayı söz gelimi İngilizceye çevirecek olursak karşımıza "winter sun" çıkacaktır ki burada "sun" kelimesinin ek almadığı görülmektedir. Ĕğer bu ifadeyi olduğu gibi Türkçeye aktarırsak, karşımıza anadili Türkçe olan herkesin yadırgayacağ 1 "kış güneş" gibi bir terkip çıkacaktır. Ne var ki dilimizin yapısına temelden aykırı olan bu kullanım, özellikle İngilizcenin etkisiyle gittikçe daha fazla yerleşmekte ve "mercimek çorba", "bayan tuvalet", "Kadıköy şube", "can yelek" gibi örneklere sıklıkla rastlanmaktadır.

Tamlanan ekine ilişkin bu durumun konumuzla ilgisi, müzikbilim benzeri terimler dolayısıyladır. Müzikoloji terimine bire bir uygunluk gözetilerek oluşturulduğu açık olan müzikbilim terimi, Türkçenin kurallarına uymamaktadır. Dilimizin yapısal özellikleri hesaba katılırsa müzik bilimi şeklinde iki kelimeden oluşması gereken terim, bu hâliyle Türkçe dil bilgisinde "ayrı yazılan birleşik kelimeler" sınıfina girmektedir. Müzik bilimi yerine müzikbilim teriminde 1 srar etmenin yol açacağ 1 sorunların başında, müzikolog karşıllı̆ında neyin kullanılacağı bulunmaktadır. Zira musicology - musicologist ikilisi model alınarak müzikolog için müzikbilimci denirse, Türkçede hiç duyulmamış "bilimci" gibi bir nitelemeye yol açılacaktır. Bilindiği üzere bir bilim dalı ile uğraşan kişilere dilimizde "âlim" veya "bilgin" denmektedir. O hâlde müzikolog yerine müzik bilgini demek daha doğru olacaktır. Fakat Türkçenin 1930'lardan bu yana devam eden büyük sorunları bu noktada da kendini göstermektedir. Çünkü 1935 yılından beri kullanıldığı anlaşılan bilgin kelimesi, yanlış türetilmiştir. Geçişli fiillerden (bıçkın, düzgün, sürgün, yorgun gibi) nesne adları yapan - gin ekinin, bilgin örneğinde, geçişli fiilden özne adı yapımında kullanıldığı görülmektedir. Bu kullanım tamamen keyfidir. Ancak türetilişindeki, çevrilişindeki, kullanımında veya telaffuzundaki hataya rağmen dile yerleşen sayısız kelime gibi bilginin de kabul gördüğü anlaşılmaktadır. O nedenle müzikoloji, müzik bilimi ile karşılandığı gibi müzikolog da müzik bilgini ile karşılanabilir. Tam bu noktada (musicology ve musicologistin ardından) 
musicological yani müzikolojik sıfatının neyle karşılanacağı sorusu akla gelebilir. Söz gelimi, müzikolojik çalışmalar terkibinin nasıl söyleneceği sorgulanabilir. Ancak tıpk1 sıfat olan koral terimi gibi müzikolojik sıfatının da kullanımından kaçınmak gerekir. Nasıl ki dilimizde koral müzik demek yerine koro müziği demek imkanı mevcutsa, müzikolojik çalışmalar yerine de kolaylıkla müzik bilimi çalışmaları denilebilir. Müzik bilimi ile müzik bilgini ikilisinin, musıki ilmi ile musıki âlimi ikilisiyle mukayese edilmesi ise Türkçenin daha başka sorunları kapsamındadır.

\section{Kimi Özel Durumlar Ve İmkanlar}

Türkçe müzik terimleri arasında öyleleri vardır ki bunlar Batı dillerindeki karşılıklarına göre daha ileri bir aşamayı ifade ederler. Bu terimlere örnek vermek gerekirse çalgl terimini söz konusu edebiliriz. Aslında çalgı, halk arasında çalgı-çengi veya çalgıcı tabirleri dolayısıyla küçümseyici bir anlam yüklenmiştir. "Kızı keyfine bırakırsan ya davulcuya varır, ya zurnacıya" gibi pek çok atasözü, deyim ve ifade ile pekiştirilmiş bu küçümseyici anlam dolayısıyla, çalgı teriminin kullanılmasında müzisyenler mütereddit davranmışlardır. Oysa ki çalgı, Batı dillerindeki karşılığına (instrument) nazaran daha ileri bir anlayışı temsil etmektedir. Çünkü Lat. kökenli instrument, aslında müzik aleti değil "alet" demektir. Örneğin ekonomik veya askerî alandaki "enstrüman"lardan söz edilmesinin nedeni budur. Ancak bu kelime, daha sonra ayrıca bir anlam daralmasına uğrayarak müzik aletini ifade eder olmuştur. Buradan açıkça ortaya çıkmaktadır ki çalgl teriminin Batı dillerindeki tam karşılığı, musical instrumenttir. Türkçe çalgl ise bu adlandırmayı tek kelimeyle karşılaması itibarıyla hem Batılı muadiline göre ileri bir anlayışı dışavurmakta, hem de Türk milletinin binlerce yıllık müzik kültürünün kıdemini, zenginliğini ortaya koymaktadır. Bu kültür mirası ise çalgıcı kelimesinin küçümsenmesi gibi yapay sorunlara çözüm olacak sayısız ayrıntıyla doludur. Çalgıcı yerine söz gelimi çalıcı denilmiş, bu terim çalıcı mehterler terkibi biçiminde müzik tarihimizin çok eski dönemlerinden bu yana var olmuştur. (Gazimihal, 1955: 11-12)

Çalgı teriminin, musical instrumentten farklı olarak, karşılık geldiği nesneyi tek kelime ile ifade ettiği için daha ileri bir adım olmasının da ötesinde, Türkçe çoksesli müzik terminolojisinde, Batı dillerinde olmayan bazı terimlerin bulunduğunu da ifade etmek gerekir. Operacı, bu terimlerden biridir. Gerçekten de sadece dilimize özgü bir niteleme olan operacı, Batı dillerinde bulunmamaktadır. Peki, bu terimle ifade edilmek istenen tam olarak nedir? Bilindiği gibi opera sanatı, içinde çok sayıda departmanı barındıran bir sanattır ve bu alanda görev yapan sanatçılardan hangilerinin operacı olarak adlandırılabileceği üzerinde netleşmek gerekir. Dekoratörden 1 ş1k tasarımcısına, kostüm kreatöründen kuaföre, marangozdan kondüvite kadar uzanan bir yelpazede çalışan elemanları bir yana bırakacak olursak, operacı teriminin rejisörlerden, orkestra veya koro şeflerinden ya da orkestra üyelerinden ziyade kumpanyadaki şarkıcıları ifade ettiği düşünülebilir. Oysa operacı terimi ön planda akla şarkıcıları getirse de Türkçe kullanımıyla pratikte opera topluluğundaki bütün müzisyenleri ve giderek bütün çalışanları anlatan bir içeriğe sahip görünmektedir. Batı dillerinde benzeri olmayan bir terim olarak son on yıllarda Türkçede gelişip yerleşen operacı teriminin eşanlamlısı olarak, Fransızca gibi bazı dillerde var olan ve nadir kullanılan, "opera adamı" anlamındaki terkipler düşünülebilirse de buradaki anlam bizdeki operacı ile örtüşmemektedir. Müzisyenleri kendi branşlarına göre, şancıları ise opera şarkıcısı olarak nitelendiren Batı dilleri, hepsini kapsayacak operacı teriminden yoksundur.

Çoksesli müzik terminolojisi söz konusu olduğunda, türetilecek terimler sadece içerikleri ya da kurallara uygun türetilip türetilmedikleri bakımından değil aynı zamanda dil biliminin diğer pek çok konu başlığı bakımından da değerlendirilmelidir. Zira dil, pek çok özelliği olan çok boyutlu bir yapıdır ve kelimelerin birbiriyle ilişkisinden doğan sayısız olgu, bu boyutlarda daha da farklı görünümler kazanmaktadır. Bu durumun müzik terminolojisine temas eden örneklerinden biri, Türkçede görülen tonlama (ezgi) özellikleri ile ilgilidir. Bilindiği gibi Türkçede tonlama veya bir kelimenin farklı hecelerine yapılan vurgu, o kelimenin hatta bütün bir cümlenin anlamını değiştirebilmektedir. Söz gelimi, tek başınayken son hecesine vurgu yapılması gereken arkadaş 
kelimesini, ikinci hecesine vurgu yapıp arkadaş biçiminde söylediğimizde, bir hitap sözü elde etmiş oluruz. Benzer biçimde "Ahmet, vardı" cümlesini "dı" hecesine vurgu yapıp ("Ahmet, vardı" şeklinde) okuduğumuzda, Ahmet'in bir noktaya ulaştığını; "var" hecesine vurgu yapıp ("Ahmet vardı") okuduğumuzda ise Ahmet'in bir zamanlar var olduğunu ifade etmiş oluruz. İşte en çok kullanılan müzik terimlerimizden biri olan çoksesli de vurgulama ile ilgili bir sorunu beraberinde getirmektedir. Her ne kadar TDK tarafindan şimdilerde çok sesli biçiminde ayrı yazılıyor olsa da müzik camiasında genellikle çoksesli olarak yazılan bu terim, bilindiği gibi sesin değil partilerin çokluğunu ifade etmektedir ve buradan hareketle onun yerine çokpartili veya benzeri bir adlandırma daha doğru olacaktır. (Bu noktada gündeme gelebilecek polifoni - homofoni ayrımı, başka bir konudur.) Çok sesli biçiminde ayrı yazıldığı zaman "sesin volümünün fazla olduğu" şeklinde algılanabilecek olan terim, çoksesli biçiminde yazıldığında da (belirtildiği üzere) bir vurgu problemini ortaya koymaktadır. Çünkü çok sesli terkibinde vurgu "çok" kelimesindeyken, yeni bir birleşik kelime olan çokseslide vurgunun son hecede olması gerekir. Oysa terimi çoksesli olarak yazan müzisyenler de vurguyu "çok" hecesine yapmaktadırlar. Yine de bu durum son derece doğaldır, çünkü terimin bir kelime olarak yerleşmesine ve ifade ettiği kavramla tam olarak kaynaşmasına bağlıdır. Benzer bir örnek olarak "ayakkabı" kelimesi verilebilir. "Ayak" ve "kap" isimlerinden oluşan kelime, bir zamanlar isim tamlaması olarak algılandığı için, belirtme hâlinde "ayak kaplarını" şeklinde söylenirken, daha sonraları birleşik kelime olarak algılanmaya başladığından "ayakkabılarını" biçiminde söylenir olmuştur. Çoksesli teriminin de kullanım sıklığına ve yaygınlığına bağlı olarak pek yakın olmayan bir gelecekte olsa da "ayakkabı"nın geldiği noktaya geleceği öngörülebilir.

Türkçede 1980'lerden itibaren karşılaşılan ve aslen gerilemeyi ifade eden bir durum, kısmen de olsa, ilginç bir biçimde müzik terminolojimizin yararına sonuçlar doğrumuştur. Söz konusu durum, 1980'lere kadar Türkçeye giren Batı dilleri kökenli kelimelerin Türkçe telaffuzlarına göre yazılmasına karşı1ık, bu tarihten sonra girenlerin orijinal imlalarıyla yazılmaya başlamasıdır. Örnek olarak, 1980'lerden çok önce Türkçeye giren bazı futbol terimleri gösterilebilir. Bu spor dalına ait "aut", "korner", "halftaym", "gol" veya "penaltı" gibi teknik terimler, orijinal imlalarıyla ("out", "corner", "half time", "goal”, "penalty") değil, Türkçe okunuşlarına göre yazılmışlardır. Oysa günümüzde bu uygulamanın tam tersinin geçerli olduğunu söyleyebiliriz. Bunu anlamak için "i-meyil" veya "insört etmek" gibi yazımların günümüzde ne kadar tuhaf geldiğini düşünmek yeterlidir. Batı dillerinde görülmeyen, Türkçeye has bu olgunun, dilimiz üzerindeki kültürel baskının boyutlarını ortaya koyduğu açıktır. Ne var ki meselenin, Türkçe müzik terimleri konusunda az da olsa olumlu sonuçları olmuştur. Buna örnek olarak arya ile aria terimleri arasındaki anlam farkı gösterilebilir. 1980'lerden çok önce daha Hüseyin Rahmi Gürpınar'da bile karşılaşıı̆ımız, "opera şarkısı” anlamındaki arya teriminin Türkçe imlasıyla yazılmasına karşılık, bir süit bölümü olan aria ise (gündelik dile yerleşmesine imkan ve gerek olmaması bir yana) orijinal imlasıyla yazılmaktadır. Bu ayrım, Türkçe çoksesli müzik terimleri açısından örnek nitelikte bir imkan olarak değerlendirilebilir. Zira hayatın doğal akışı içinde oluşmuş ve dilin kendi dinamikleri üzerinde şekillenmiştir.

\section{Birtakım Öneriler}

Müzik terimciliğimizin neredeyse yüz elli yılı bulan serüveni içinde pek çok değerli müzikbilimci ve bestecinin çabaları düşünüldüğü zaman, ilginç bir biçimde iki noktanın dikkatten kaçtığ 1 ya da layıkınca değerlendirilemediği görülmektedir. Bunlar, klasik Türk musıkisinin yapay olmayan, köklü ve tarihsel 1stılahlarıyla (terimleriyle) bir alışverişin, ortak bir zeminin tesis edilememesi ve çoksesli müzik pratiğinin temelini oluşturan provalarda, performansın asli süreci içinde hayat bulmuş olan prova terimlerinden yeteri kadar yararlanılamamış olmasıdır. Bu iki imkandan birincisinin, müzik terminolojisi üzerine çalışllan on yıllar boyunca Türkiye'de kendini hissettiren keskin ideolojik kırılma dolayısıyla değerlendirilmesinin çok güç olduğu anlaşılabilir ise de, çoksesli müzik camiasının sahip olduğu prova kültürünün yansıması olan terimlerin değerlendirilememesi, şaşırtıcı bir durumdur. Yine de şaşırtıcı olduğunu söylediğimiz bu durumun 
nedenini tespit etmek güç değildir: Müzikolog, besteci ve müzik eğitimcisi kadroların müzik pratiğine yakın olamamaları, aktif müzikle uğraşan orkestra şefi, koro şefi, piyanist ve benzeri müzisyenlerin ise terimler üzerine düşünmelerine izin verecek müzikolojik ilgi ve donanımdan genel olarak yoksun bulunmaları... Neticede kaçırılan bu firsat, çoksesli müziğimiz ve bu alandaki terimciliğimiz için belki de hiç farkında olunmayan büyük kayıpları beraberinde getirmiştir. Çünkü prova terimleri üzerinde durmak, hem pek çok kavram üzerinde yeniden ve reel olarak düşünmek, hem de çağımızda çoksesli müziğin en önemli meseleleri arasında olan teori-pratik birlikteliğini temin etme imkanı yakalamaktır. Aşağıda önce klasik Türk musıkisi 1stılahları, sonra da prova terimlerine ilişkin örnek nitelikte birtakım önerilerde bulunulacaktır.

Klasik Türk musıkisi ile çoksesli müziğin, temel kabulleri ve protokolleri bakımından birbirinden oldukça uzak iki müzik kültürü olmaları, her ikisinin de özü itibarıyla müzik oldukları gerçeğini değiştirmemektedir. Dolayısıyla bu iki tür arasında müşterek kullanılabilecek terimler, çoğu kere zannedildiğinden fazladır. Karar vermek, bu terimlere örnek gösterilebilir. Seslerin yürüyücülük ve duruculuk özelliği ile kronos içinde var olan müzik sanatının her türünde kadans veya (adına ne denirse denilsin) duruş olacağ açıktır. Klasik Türk musıkisinin, bu olgu için tercih ettiği fiil, son derece köklü; dilimizde, edebiyatımızda, düşünce ve kültürümüzde önemli yeri, türevleri, bağlantılı deyim ve atasözleri bulunan "karar vermek" fiilidir. Bir yerde "karar etmek" ("yerleşmek"), "istikrar", "tekrar", "kere", "karar vermek" (İng. understand fiili benzeri: "to stand", "durmak") ifadeleri, bu fiilin gücünü ve çağrışım alanını göstermeye yeter. Çoksesli müzikte kullanılan ve kadans karşıllğında türetilen durgu terimi ise artık hiç yabancılık çekilmeyen, oldukça yerleşmiş bir terim olmasına karşın (Bakihanova, 2003: 15) kararın gücüne ve çağrışım alanına sahip değildir. Çoksesli müzikteki kadans ile klasik Türk musıkisindeki kararın aynı şey olmadığı, burada bir analojiye düşüldüğ̈̈ ve terimlerin farklı olmasının bu nedenle doğal hatta gerekli olduğu öne sürülebilirse de, bu, her iki müzik türü arasında bir terminolojik alışveriş potansiyeli bulunduğu gerçeğini değiştirmez. Unutulmamalıdır ki Türk müzik kültüründe farklı türler arasındaki ayrım, Ortaçağ İslam medeniyetinin bazı özellikleri nedeniyle oldukça belirsizdir. $\mathrm{Bu}$ bakımdan klasik Türk musıkisi ile Türk halk müziği arasındaki inkar edilemeyecek maddi yakınlıtan yola çıkarak, benzer bir ortak dilin (her iki türün farklı materyal ve felsefeye sahip oldukları gerçeği 1skalanmadan) klasik Türk musıkisi ile çoksesli müziğimiz arasında da tesis edilebileceği önerisi dikkate alınmalıdır.

Aslında bu iki müzik türü arasındaki terminolojik etkileşim, çoğu kere zannedildiğinden daha geniştir. Senfoni veya opera orkestralarımızda yaylı çalgıcıların kullandığı rahle terimi, bu konuda verilebilecek oldukça çarpıcı ve uç bir örnektir. Tamamıla Osmanlı kültüründen gelen rahle, orkestralarımızda sadece nota sehpasını ifade eden somut bir anlam değil, (örneğin) kemancılar arasındaki hiyerarşiyi anlatan soyut bir mana da taşımaktadır. Benzer şekilde, klasik Türk musıkisinden alınma perde terimi de, çoksesli müziğimizde kullanılmaktadır. İng. pitch bir yana, dilimizde daha çok ton ile karşılanan kavramın karşılığı olarak zaman zaman ses veya nota denildiği görülmekte ise de, bu ikisinin ton terimini karşılamasının mümkün olmadığı açıktır. Oysa perde, tonun tam karşılığıdır ve zwelftonteknikin çevirisi olarak kullanılan onikiperde tekniği teriminde görüldüğü gibi azımsanamayacak bir yaygınlık kazanmıştır. Bu hususta son olarak; perde veya rahle gibi terimlerin çoksesli müzik terminolojimize girmesinde ilk çoksesli müzikçilerimizin ve müzikbilimcilerimizin klasik Türk musıkisi kökenli olmalarının etkili olduğu, ancak yeni gelen kuşaklarda bu durum değiştiği için iki tür arasında kısmen de olsa ortak bir adlandırma zemini oluşturulamadığ söylenebilir.

Çoksesli müzik terimciliğimizin ne yazık ki büyük oranda 1skaladığı diğer alan ise, müzik pratiğinin temelini oluşturan provalarda, performansın asli süreci içinde hayat bulmuş olan prova terimleridir. Bugün herhangi bir müzik sözlüğünde, hatta ansiklopedisinde, bunların yanısıra müzik eğitimi kitaplarında prova terimlerinin hiç yer almadığı görülmektedir. Prova terimleri, meslek dilimizde (tabiri caizse) konservatuvar, akademi veya teori dişı bir üst dil, jargon hatta argo gibi bulunmakta ve algılanmaktadır. Halbuki bunu kesinlikle hak etmeyen bu terimler, yukarıda da

Turkish Studies - Social, 15(1) 
değinilmiş olduğu gibi, hem pek çok kavram üzerine yeniden ve reel olarak düşünmek, hem de çağımızda çoksesli müzik sanatının en önemli sorunsallarından birini teşkil eden teori-pratik birlikteliğini (yukarıda da ifade olunduğu üzere) temin etmek bakımından paha biçilemez önemdedir.

En bilindik prova terimlerinden çekmek ve koşmak, bu terimlerin aktif müzikle nasıl iç içe olduklarına ilişkin güzel birer örnek teşkil etmektedir. Bilindiği gibi çekmek, "bir orkestra veya koro provasında, topluluğun tempoyu farkında olmadan ağırlaştırması" anlamına gelirken, koşmak ise bunun tam tersi olarak "grubun tempoyu bilinçsizce hızlandırması" anlamına gelmektedir. Ülkemizde orkestra veya koro şefi ya da tutti eleman olarak bu toplulukların provalarında bulunmuş her müzisyen, bu terimleri ve anlamlarını bilir. Dolayısıyla çekmek ve koşmak terimlerinin hiç olmazsa bir müzik sözlügüunde bulunması elzemdir. Çekmek ve koşmak gibi Türkçe kökenli olan bir başka prova terimi de akış almaktır. "Uzun minutajlı olduğu için kısım kısım çalışılma mecburiyeti olan yapitlarda veya bölümlerde provaların belli bir aşamaya ulaşması sonucunda, yapıtın veya bölümün baştan sona kadar hiç durmadan seslendirilmesi"ni ifade eden bu terim de yine bütün orkestra şeflerinin ve orkestra üyelerinin sıklıkla kullandığı bir terimdir. Bununla birlikte maalesef herhangi bir müzik sözlüğünde kendine yer bulamadığı görülmektedir.

Prova terimleri, çekmek - koșmak veya akış almak gibi açık ve anlașılır ifadelerden ibaret değildir. Bir kısmı, çok daha spesifik olguları adlandıran kelimelerdir. Örneğin ezmek, yaslanmak ve oturmak gibi bu gruba giren prova terimlerinin, şan eğitimi almamış, özellikle de opera korosunda söylememiş kişiler tarafından bilinmesi, anlaşılması kolay değildir. Bunlardan birincisi tamamen şan tekniği ile ilgiliyken, ikincisi "provaya yeteri kadar hazır olmayan bir koristin, yanında söyleyenleri dinleyip onlara dayanarak ikircikli söylemesi”ni, üçüncüsü ise "şancının, sesi pozisyonda olacak şekilde belirli bir perdeye yerleşmesi"ni anlatmaktadır. Yine beyaz ses, kemikli ses, etli ses veya ăgır ses gibi artık terimleşmiş terkipler de bütün şancıların meslek hayatlarında her gün duyup kullandığı adlandırmalardır. Bunlardan beyaz ses, "pozisyonda olmayan ses"i, kemikli veya etli ses, "dönüş yeri (sırasıyla) belirgin olan veya olmayan ses"i, ağır ses ise "ajilite kabiliyeti sınırlı olan ses"i anlatmaktadır. Opera-şan alanı dışındaki müzisyenlerin, insan sesini veya şan tekniğini bilmiyor olabilecekleri kabul edilse de en azından bu olgulardan ve terimlerden haberdar olmanın gerçekten önemli olduğu kabul edilmelidir. Zira tonal müziğin neredeyse tamamen üzerinde ş̧ekillendiği legato çalış, gerçek anlamda ancak insan sesinden öğrenilebileceği gibi, "kontrpuan" denilen ve armonik fonksiyonların da temelini oluşturan teknik, (o dönemin kiliselerine enstrüman giremediği için) sadece insan sesi temel alınarak geliştirilmiştir. Tüm bunlar bir yana bırakılsa bile, örneğin ă̆ır ses teriminin, ajilite kabiliyetindeki snnılılığ 1 ifade etmesi bakımından hemen her müzisyenin ilgi ve bilgisi dahilinde olması gerektiği açıktır. Ancak böyle olursa bir müzisyen, mesela dramatik koloratur ses renginin, Paganini'nin keman konçertosunu seslendiren bir viyolonsele benzediğini idrak edebilecektir.

Prova terimlerinin opera sanatı kapsamında olanları sadece teknik tabirlerle sınırlı değildir. Bunun dışında da operanın kendi ihtiyaçları doğrultusunda geliştirdiği pek çok terim bulunmaktadır. Son olarak bu terimlere örnek gösterilebilecek olan kupürden kısaca söz etmek gerekirse, terimin, Fransızcada "kesmek" kökünden türetilmiş olan "coupure" kelimesinden geldiği belirtilmelidir. Bilindiği gibi Türkçede kupür, gazeteden kesilen parça veya kağıt para birimi demektir. Ne var ki operada bu kelime, teknik bir terim hüviyetine bürünmüş ve tiyatroda metnin rejisör tarafından kısaltılması anlamına gelen budama terimine benzer biçimde, partiturun, orkestra şefi ve/veya rejisör tarafından bazı gereklerle kısaltılması anlamını kazanmıştır. Yerine başka bazı terimler de kullanılıyor olsa bile kupür, sadece anlamı değil renkli çağrışım alanı ve imitatif karakteriyle de üzerinde durulması gereken bir terimdir. Ne var ki o da diğer sayısız prova terimi gibi, müzik terimlerini içeren kaynaklarda yer almamaktadır. 


\section{Sonuç}

$\mathrm{Bu}$ makalede öne sürülen düşüncelerden hareketle çoksesli müzik terimciliğimiz için bulunulabilecek önerilerden ikisinin, klasik Türk musıkisi ile temas ve prova terimlerinden istifade olduğu söylenebilir. Terim türetme konusunda ise bir bilim veya sanat dalında (ya da felsefede) Türkçe terim türetmenin, sadece o alana değil, Türkçeye de hatta türetilecek terimin diğer dillerdeki karşılığına da hakkıyla vakıf olmayı gerektirdiği belirtilmelidir. Bu açıdan bakıldığında terim türetmenin, kişisel olduğu kadar kolektif bir çabayı da gerektirdiği açıktır. Ne var ki günümüz, bırakalım moderniteyi, post-modern dönemleri bile çoktan geride bırakmıştır ve dolayısıyla 1930'lu, 40'lı yılların ulus-devlet çatısı altında şekillenen "muasır medeniyet" ideali kapsamındaki millî ve merkeziyetçi eğitim (bu arada müzik eğitimi) politikalarıyla mümkün olabilecek bir ortak terminoloji dilini bugün var edebilmek çok zordur. Serbest pazar ekonomisi ve kentleşmeye doğru aldığı yol ile karakterize olan günümüz Türkiyesi, dünya genelinde iletişim ve ulaşım bakımından yaşanan gelişmelerden de bağışık değildir. İçinde bulunduğumuz dünya; bütün kültürlerin, dillerin ve sanat dalların çok hızlı bir etkileşim içinde olduğu, içeriklerinden arındırılmış salt biçimlerin kolaylıkla imite edilebildiği, eğitimli bireylerin gittikçe kozmopolitleştiği ve çok çabuk tüketilen eklektik ürünlerden oluşan bir piyasanın herkesi domine ettiği bir dünyadır. Böyle bir dünyada, modernizmin ilham ve imkan verdiği bir millî kültür tablosu çizebilmek çok zordur. Bu tablonun figürlerinden birini oluşturacak çoksesli müzik terminolojisi de aynı engellerle karşılaşacaktır ve karşılaşmaktadır.

Öte yandan, tüm bu argümanlara karşın Fransa ve özellikle Almanya gibi kentleşmiş, kapitalist sanayi ülkelerinin oluşturup muhafaza ettikleri millî kültürler de bir vakadır. Söz gelimi Almanya, siyasal ve ekonomik alanda dünyanın en büyük güçlerinden biri olarak teknoloji, iletişim ve ulaşım alanlarındaki önemli imkanlarıyla post-moderniteyi tam olarak yaşayan bir ülke olmasına karşın, bilimden sanata ve felsefeye, oradan dile ve nihayet bütün bir kültürüne millî karakter kazandırmayı bilmiştir. Alman müzisyenleri, Türk meslektaşlarına nazaran çok daha fazla uluslararası etkileşimde bulunmalarına rağmen, kullandıkları müzik terminolojisi Türkçe çoksesli müzik terminolojisine göre çok daha millî karakterdedir. Dolayısıyla Türkiye'de bir Türkçe çoksesli müzik terminolojisi meydana getirmek imkansız değildir. Ancak bunun merkezî bir koordinasyonla yapılması bugün için mümkün görünmemektedir. Geriye sadece yetenekli ve çalışkan müzikologlarımızın bu alanda gerçekleştirecekleri bireysel çalışmalar kalmaktadır. Bu yönde verilecek nitelikli ve kapsamlı ürünler, benzer çabaların içinde olan meslektaşlar arasında bir işbirliği ve eşgüdüm sağlayabilir. Bu çabaların meyvesinin gerçekten toplanıp toplanamayacağı, yurt genelinde çoksesli müzik terminolojisi konusunda ortak ve tutarlı bir dilin ve tavrın geliştirilip geliştirilemeyeceği, hele de bunun Türk müzik hayatına ve pratiğine olumlu yansıyıp yansıyamayacağı ise ayrı bir çalışmanın konusudur.

\section{Kaynakça}

Bakihanova, Z. (2003). Armoni. Ankara: Bilkent Üniversitesi.

Hodeir, A. (2003). Müzikte Türler ve Biçimler. İstanbul: Pan Yayıncılık.

Gazimihal, M. R. (1955). Türk Askerî Muzıkaları Tarihi. İstanbul: Maarif Basımevi.

Gazimihal, M. R. (1961). Musıki Sözlüğü. İstanbul: Millî Eğitim Basımevi.

İmer, K., Kocaman, A., Özsoy, A. S. (2011). Dilbilim Sözlüğü. İstanbul: Boğaziçi Üniversitesi Yayınevi.

Korsakov, N. R. (1996). Kuramsal ve Uygulamalı Armoni. İzmir: Diztek.

Nişanyan, S. (2019). Kelimebaz. İstanbul: Liberus Yayınları.

Turkish Studies - Social, 15(1) 
Sinanoğlu, O. (1978). Bilim Kültür ve Öğretim Dili Olarak Türkçe. Ankara: Türk Tarih Kurumu Basımevi.

Stravinsky, I. (2000). Altı Derste Müziğin Poetikası. İstanbul: Pan Yayıncılık.

Uz, K. (1964). Musiki Istılâhatı. Ankara: Küğ Yayını.

Zülfikar, H. (2011). Terim Sorunları ve Terim Yapma Yolları. Ankara: Türk Dil Kurumu Yayınları 